\title{
Novice Teachers (in the Creating Process of) Forming Professional Career Thinking and Teachers Beliefs
}

\author{
Milon Potmesil, Stefan Chudy, Pavel Neumeister, Jitka Plischke, Richterova Bohdana \\ Olomouc Department, Faculty of Education, Palacky University, Olomouc, Czech Republic \\ Email: mvpotmesil@gmail.com, milon.potmesil@upol.cz
}

Received September 2014

\section{Abstract}

The purpose of this study is to identify a process of forming professional career thinking and teachers beliefs. The process is creating on mapping approaches in upbringing in the process of professional thinking of novice teachers. The primary objective of this study is to show methodological possibilities of mapping the process of forming professional career thinking and beliefs of future teachers in the undergraduate training. Undergraduate training then, in relation to the nature of the study, can be simply described as the process of transition from education to the subjective theory of general formal representation of knowledge based on universally shared semantic structure. The study is conducted with the participation of 5 (small focus group) novice teachers on Czech Republic. Novice teachers write essays on the theme "Education process of my beliefs after a one year work on school" and write report (free literacy form) on the questions: "What do you think education is?" "Who participates in education?" "How does education work?" Then was the report of analyses by Meaning Constitution Analyses (MCA) method and its software version Minerva is based on a self-report of an examined person.

\section{Keywords}

Novice Teachers, Meaning Constitution Analyses (MCA), Teachers Beliefs, Metodological Possibilities of Meaning Constitution Analyses (MCA), Teachers Professional Career

\section{Introduction}

Teacher education is one of the key problems of contemporary science education. There is a prevailing general belief that especially the initial teacher training and education significantly affects the quality of education in schools, where teachers work. A fundamental rethinking of teacher training after 1989, consisting in the implementation of performance-based approaches, brought into the Czech education system new general category of competence-refers to the competence of pupils, the teacher's competence. The idea behind this change is the move from assessment of learning outcomes through adoption rates prescribed by the contents of the assessment of professional competencies-specific performance criteria, specific performance [1]. Inconsistent definition of 
teacher professional competence, including lists of qualifications, teacher characteristics, skills, etc., T. Janik summarizes in terms of the complex potentialities leading to successful "effective" materialization of the teaching profession [1]. One of the key components of planes or forming part of the professional competence of teachers is also teacher's implicit theories [2] or teacher beliefs. The process of formation and transformation of subjective theories of teachers in the process of undergraduate teacher training as a specific set of knowledge (in the narrower sense) are the key issue of the study. Our concept is based on the belief that theories are subjective contents of the human world of meanings which an individual, in accordance with the rules of phenomenological philosophy, forms the basis of the experience of this world. The majority concept of the subjective theories, however, approaches to the concept of a human as a scientist and subjective theories similarly characterizes as "scientific" theory of stages through systematic, argumentative structure or language formability [3]. On the contrary, this attitude, of course, degrades the subjective theory as the antithesis to the scientific theory, and the process of undergraduate preparation is then perceived as a shift from subjective theories to the scientific theory or reconstruction of subjective theories in scientific theory.

\section{Philosophical Approaches}

Phenomenology offers an alternative view on the issue. Phenomenology cannot be seen as a philosophy or philosophical school, but in accordance with its founder Edmund Husserl as an attempt to substantial revision of the whole philosophy based on a thorough revision of the doubt and the relationship of the knower and recognizable entities. Ivan Blecha [4] characterizes phenomenology as a specific way of looking at the world and as an attempt to purify the consciousness from all interventions of objective reality. An important aspect of phenomenology is the systematic analysis of the basic structures of the lived experience of the world-the natural world (Lebenswelt in German-the "natural world") as the last basis which gives meaning to all other activities (from the current understanding of the world to its scientific interpretations). The central thesis of phenomenology, i.e. undetectability and unknowability of clean reality which is exempt from the subject, and the focus on the knowledge through experiencing, or experience of the subject can be transformed into specific categories, the socalled phenomenological attitude. The phenomenological attitude is exploring things and phenomena not as the things given, but as things which appear to us in a particular way. The primary and most important is just that the things appear to us through the fact how important they are for us and our subjective sense in the life-world. Within the phenomenological attitude it is necessary to follow three basic rules of research [5]. The rule of epochédisregarding of all own knowledge, prejudices, preconceptions. What matters in this field is bracketing of all self-knowledge and access to the new situation.

The rule of description-highlighting of the role of the researcher as a person who is describing rather than explaining. The researcher using his or her own explanations would put in his or her own subjective meanings to the testimony of others. The rule of horizontalization-based on Husserl's thesis that things appear to us in so called horizons. This is due to the obligation of the researcher to perceive the individual data as equal, not try to hierarchize. The phenomenological approach, whose general framework we have outlined, allows a change of perspective and perception of exploration of subjective theories of education, and thus open up new areas for research on the importance of subjective theories in the undergraduate teacher training. Instead of the traditional allocation of the amount of subjective and scientific theories, which emphasize scientific theories, the phenomenological approach emphasizes the importance of subjective theories as a result of the experience of education, as a product of the reflection of the content of education to the students' personal subjective system of teacher training courses. This fact also formulates the basic research question of the study.

How is the general theory of education in the form of formal ontology reflected in the natural world of the teacher novice? It can be assumed that through the course of general education as part of undergraduate education in the natural world the student's basic educational categories in clearly formalized representation of the concept based on accepted and shared meaning structure will be reflected. Simply said, it can be argued that the student of education adopts the specific conceptual structure of the discipline. Or on the contrary, it can be stated that he or she reconstructs this formalized representation based on his or her meanings, corresponding with the natural world.

\subsection{Formal Ontology of the Teacher's World on the Theory of Education}

Education as a social process is common to all companies and individuals. Through education reproduction and 
development and integration of the individual into it is ensured. Each company (globally), as well as each individual (with a range on a specific group of people-e.g. while raising their own children) creates its own subjective theory of education. The starting point of these theories is a set of questions relating to the various actors in the process of education. Answering these questions (e.g. adherence to one of the possible answers) is the basis for building a personal or general theory of education as well as the diversity of the various theories. In order to create an overview of the basic dilemmas theory of education is necessary to find a meta-theory of education, the theory that describes all the major players in education-learning process. Through this meta-theory differences between theories of education can be described. A suitable meta-theory of the education system presents B. Bližkovský [6]. The advantage of the system theory is the interdependence of the various participants in the system, and emphasis on the internal dynamics, based on the dialectical relationship among these actors. The principal actors in the system theory of B. Blížkovský are:

- subjects of education-who raises,

- objects of education-who is the addressee of education,

- aims of education—for what purposes, for what, why to raise,

- parenting resources-how, by which means to educate (actors, institutions, organizational forms, contents and forms of education, educational resources, succession process, etc.),

- the terms of education-that external and internal conditions affecting the form of education, how processes of education reflect changes in the environment of individual actors of education.

Processing of these issues, their empirical argumentation, creates specific scientific theories of education which become the content of the curriculum of the undergraduate teacher training. The completed form is then presented as sets of predetermined information within the introduction to the discipline of pedagogical sciences, which have in Czech pedagogy concept called the general education (foundation of education or theory of education). It is necessary to emphasize the crucial influence of the German classical pedagogy (Allgemeine Pädagogik of Johann Friedrich Herbart). General pedagogy is therefore traditionally conceived as the system pedagogy, as the central discipline with normative control on other disciplines of pedagogy, whose task is to carry out the synthesis of knowledge, and generate the general theory of education [7]. The aim of this discipline is to place a student of pedagogy on a specific content and semantic base, then to equip him of her with concepts, which will be transferable within different contents of sciences on education. This conception of education can best be termed as formal ontology. Although the original ontology is a philosophical term, characterizing the issue of entity and being, it is currently preferred especially in the field of computer science as a formalized representation of knowledge designed for sharing and reusing. The principle of formal ontology in computer science is therefore to create structures and tools of common share of recognized descriptions of individual entities [8]. Why do we use the term formal ontology in this study? The reason is that the concept of theory of education within the undergraduate teacher training plays the role of formal ontology, especially in the following areas:

-It is the formalized representation of knowledge intended for sharing;

-It is the shared terminology for a particular application sphere;

-It is the representation of concepts based on universally shared meaning structure and terminology of the sphere.

\section{Methodology of Research}

Following the already introduced phenomenological approach, we chose phenomenology of meanings of the Swedish author Roger Sages known as MCA (Meaning Constitution Analyses). The main benefit of this method is the attention given to individuals creating their natural world through constituting of meanings. Sages's Meaning Constitution Analyses method and its software version Minerva is based on a self-report of an examined person. The research was conducted on a focus group: 5 novice teachers.

\subsection{Course of Research}

The instruction assignment was in accordance with the recommendations of R. Sages entered general, in order to affect their answers the least. Therefore, as the entry of the self-reports students were entered a written task to characterize education in their own words with accompanying questions: "What do you think education is?" 
“Who participates in education?" "How does education work?” The second step of the analysis was the division of the text to meaning units. This step is an example of the application of Husserl's principle of epoché where a distribution via text on basic semantic unit retreats from the researcher's own pre-understanding.

Within the third step modalities of the meaning were determined. They were made for each semantic unit. The modalities of meaning indicate a way of a specific creating of meaning by an individual. By stating of the modalities, the knowing subject is separated from the recognized object. The recommended modalities according to R. Sages are 1. Belief, 2. Funcion, 3. Time, 4. Affect, 5. Will, 6. Property, 7. Subject.

The first three steps of the research process of R. Sages are part of a complete analysis of the structure of meaning-noema. Through the fourth step the Minerva program is used for the synthesis of the data received. As the fourth step, R. Sages recommends to analyze partial intentions. In each meaning units, partial intentions are divided to so-called entities (that what exists), and predicates (what is said about the entity). By this process the very structure of meaning is achieved, since each partial intention forms part of the meaning expressed by the respondent. It sets a given respondent's pre-understanding of the phenomenon and its experience from which it is based.

\subsection{Results of Research}

As part of the research we have collected testimonies of the respondents. Out of these respondents, for the sake of a sample, 5 responses of the students were randomly selected. This testimony is presented. A detailed analysis is included in this study. In the context of the synthesis, the summary results of processing statements on the basis of which the following interpretations are presented (Figure 1).

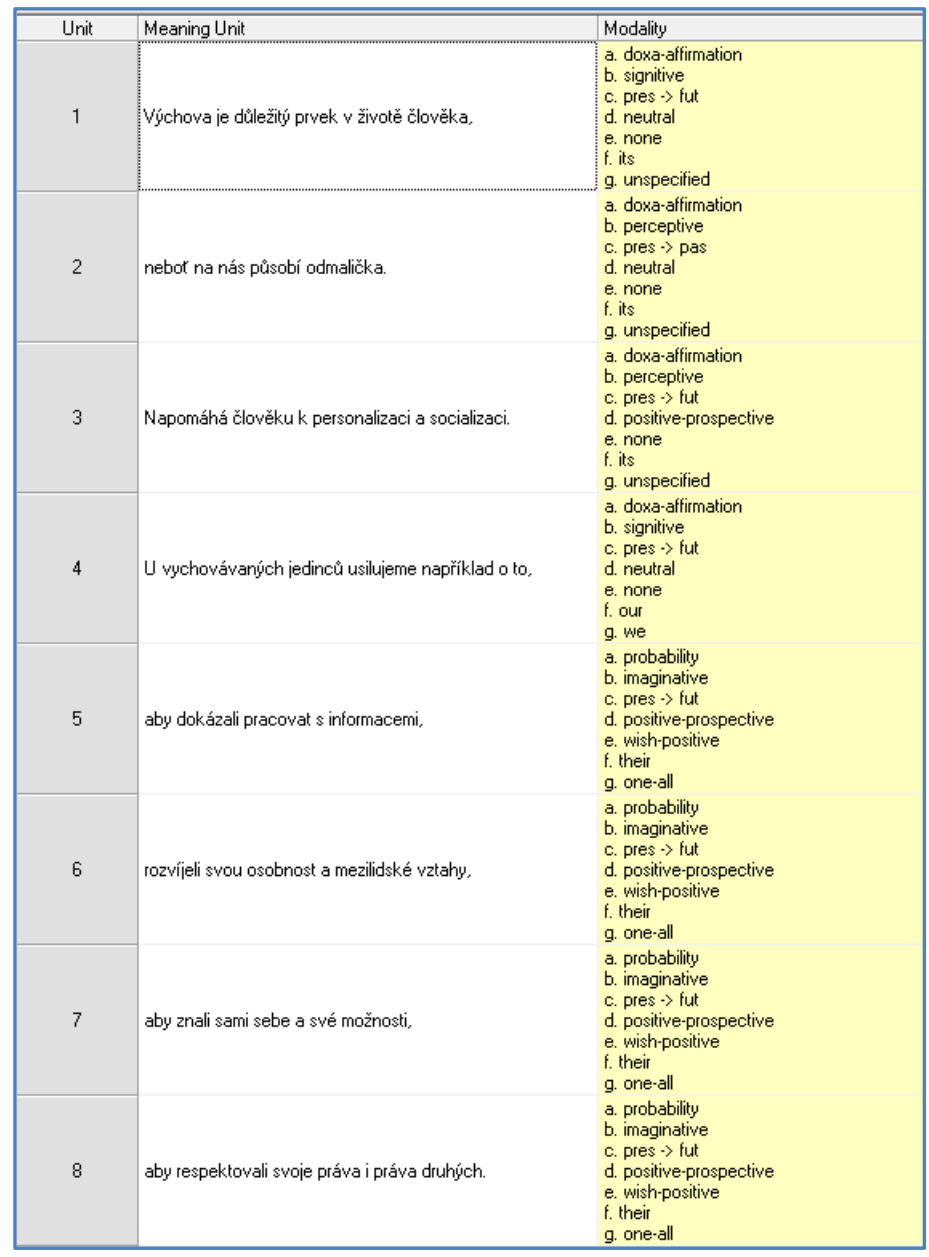

Figure 1. Modality chart (part of results from software). 
The system of using modalities presents the specific individual approach to the life-world and the way of understanding to the life-world. It shows how the respondents understand the world. It is also important to realize that, all partial intentions considered of equal value in the beginning of the process of analyses. A partial intention contains part of the total meaning of the intentional object expressed in a way characteristic form the individual. The meaning contained in the partial intention is called the entity, ant the way of expressing it, its predicate. An entity is what appears as something that exists for the experiencing individual [9]. Here follows three examples of the relationships between entities, predicates and modalities (Figure 2 and Figure 3).

\begin{tabular}{|c|c|c|c|c|}
\hline Modality & Category & Meaning Unit & Freq & R Freq \\
\hline \multirow{4}{*}{ Affects } & negative-prospective & 16 & 1 & $4,17 \%$ \\
\hline & negative-retrospective & 21 & 1 & $4,17 \%$ \\
\hline & neutral & $1,2,4,9,10,11,12,13,14,17,18,19,20,23,24$ & 15 & $62,50 \%$ \\
\hline & positive-prospective & $3,5,6,7,8,15,22$ & 7 & $29,17 \%$ \\
\hline \multirow{3}{*}{ Belief } & doxa-affirmation & $1,2,3,4,9,10,11,12,13,14,15,17,18,19,20,22,23,24$ & 18 & $75,00 \%$ \\
\hline & doxa-negation & 16,21 & 2 & $8,33 \%$ \\
\hline & probability & $5,6,7,8$ & 4 & $16,67 \%$ \\
\hline \multirow{3}{*}{ Function } & imaginative & $5,6,7,8,10,16$ & 6 & $25,00 \%$ \\
\hline & perceptive & $2,3,9,12,14,15,18,19,20,22,23,24$ & 12 & $50,00 \%$ \\
\hline & signitive & $1,4,11,13,17,21$ & 6 & $25,00 \%$ \\
\hline \multirow{5}{*}{ Property } & his & 11.12 & 2 & $8,33 \%$ \\
\hline & its & $1,2,3,9,13,16,17,19,20,22$ & 10 & $41,67 \%$ \\
\hline & my & 10 & 1 & $4,17 \%$ \\
\hline & our & 4 & 1 & $4,17 \%$ \\
\hline & their & $5,6,7,8,14,15,18,21,23,24$ & 10 & $41,67 \%$ \\
\hline \multirow{4}{*}{ Subject } & & 20,23 & 2 & $8,33 \%$ \\
\hline & 1 & 10 & 1 & $4,17 \%$ \\
\hline & one-all & $5,6,7,8,18$ & 5 & $20,83 \%$ \\
\hline & unsoecified & $1.2 .3 .9 \cdot 11 \cdot 12 \cdot 13 \cdot 14 \cdot 15 \cdot 16 \cdot 17 \cdot 19 \cdot 21 \cdot 22 \cdot 24$ & 15 & $62.50 \%$ \\
\hline
\end{tabular}

Figure 2. Partial Intentions classified by entity.

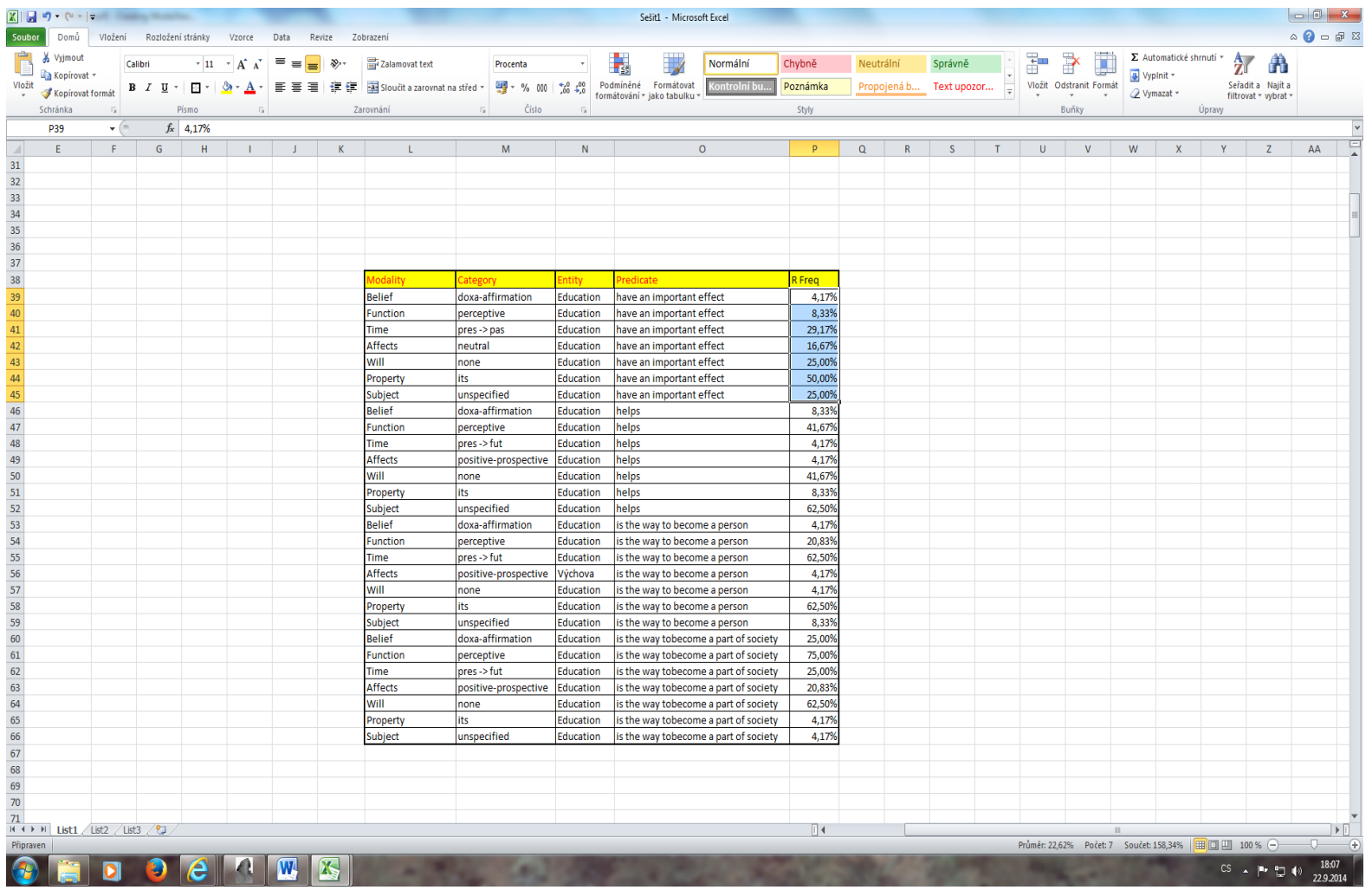

Figure 3. Most frequented predicates related to the entity "Education”. 


\section{Conclusion}

The results show that the students after completion of the discipline general pedagogy partly change the meaning of the general categories of educational processes. The main category, which construct the processes of education are: education (in Czech výchova), child (in Czech dítě), self-cognition (sebepoznání), and authenticity of human being. It also indicates what sort of more or less modified types and kinds of experiences the individual is moving toward (the future dimension of education). Most entities are expressed in a signified function modality, implying that their concern something abstract. The entity "education" is mentioned in a perceptive Functioned modality. Every entity is expressed in a present time, except "meaning of education” which seems to be "change". The change is something taking place in the continuous. The group of complete noema taken together constitutes the life-world of subject connected to the process of education.

After the text edit has been completed, the paper is ready for the template. Duplicate the template file by using the Save As command, and use the naming convention prescribed by your journal for the name of your paper. In this newly created file, highlight all of the contents and import your prepared text file. You are now ready to style your paper.

\section{Acknowledgements}

Internal grant of PDF UP: From subjective implicit theories of education to teaching knowledge. The process of constitution of a cognitive framework sciences education in the national and international context.

IGA PdF 2014004: Mapping approaches to describe fragments and constructs training for new teachers at Faculty of Education on UP in Olomouc.

The VOICE of European Teachers (VOICES), 526613-LLP-2012-NL-Comenius-CNW.

\section{References}

[1] Janík, T. (2005) Znalost jako klíčová kategorie učitelského vzdělávání. Paido, Brno.

[2] Clark, C.M. and Peterson, P.L. (1986) Teachers Thought Processes. In: Wittrock, M.C., Ed., Handbook of Research on Teaching, MacMilllan, London.

[3] Schlee, J. and Wahl, D., Eds. (1978) Veränderung subjectiver Theorien von lehrern. Universität Oldenburg, Oldenburg.

[4] Blecha, I. (2006) Proměny fenomenologie—Úvod do Husserlovy filosofie. Triton, Praha.

[5] Strobachová, B. Roger Sages, fenomenologie významu a MCA. In. Gulová, L. and Šíp, R., Eds., Výzkumné metody v pedagogické praxi, Grada Publishing, Praha.

[6] Blížkovský, B. (1997) Systémová pedagogika pro stadium a tvưrčí praxi. Amosium Servis, Ostrava.

[7] Lenzen, D. (1998) General Theory of Education; A Subdiscipline or the Central Discipline of Educational Studies? Education, 56, 77, 98.

[8] Svátek, V. (2002) Ontologie a WWW. In. Datakon. Cz.

[9] Sages, R. and Lundsten, J. Meaning Constitution Analyses: A Penomenological Approach to Research in Human Sciences. (On-Line) http://www.iaccp.org/drupal/sites/default/files/spetses_pdf/22_Sages.pdf 